\title{
In vitro plant regeneration system for common bean (Phaseolus vulgaris): effect of $\mathbf{N}^{6}$-benzylaminopurine and adenine sulphate
}

\author{
Andrés M. Gatica Arias* \\ Escuela de Biología \\ Universidad de Costa Rica \\ P.O. Box 2060, San Pedro, Costa Rica \\ Tel: 5062075091 \\ Fax: 5062074216 \\ E-mail: agatica@biologia.ucr.ac.cr \\ Jenny Muñoz Valverde \\ Escuela de Biología \\ Universidad de Costa Rica \\ P.O. Box 2060, San Pedro, Costa Rica \\ Pilar Ramírez Fonseca \\ Escuela de Biología \\ Universidad de Costa Rica \\ P.O. Box 2060, San Pedro, Costa Rica \\ Marta Valdez Melara \\ Escuela de Biología \\ Universidad de Costa Rica \\ P.O. Box 2060, San Pedro, Costa Rica
}

Financial support: This research was supported by the University of Costa Rica (Grant No. 111-A4-013) and the National Commission of Scientific and Technological Investigation of Costa Rica (Consejo Nacional de Investigaciones Científicas y Tecnológicas, CONICIT) (Grant No. FV-025-03).

Keywords: common bean, in vitro culture, morphogenesis, Phaseolus vulgaris L., plant growth regulators.

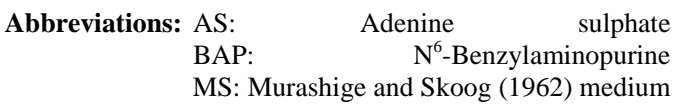

A method for regeneration of the commercially important common bean (Phaseolus vulgaris) using $\mathbf{N}^{6}$ benzylaminopurine(BAP) and adenine sulphate (AS) was established. Embryogenic axes of the Costa Rican common bean cultivars Bribrí, Brunca, Guaymí, Huetar and Telire were cultured on Murashige and Skoog medium supplemented with $100 \mathrm{mgl}^{-1}$ myo-inositol, 1 $\mathrm{mgl}^{-1}$ thiamine, $30 \mathrm{gl}^{-1}$ sucrose, BAP (0, 5 and $\left.10 \mathrm{mgl}^{-1}\right)$, AS (0, 20 and $40 \mathrm{mgl}^{-1}$ ) and $8 \mathrm{gl}^{-1}$ agar. Regardless of the concentration of BAP and AS in the induction medium, the number of shoots and leaves differed significantly among the common bean cultivars evaluated. The higher average of shoots was obtained for Brunca > Telire > Bribrí > Guaymí > Huetar. Moreover, independently of the cultivar, the induction medium supplemented with $5 \mathrm{mgl}^{-1}$ BAP and 20 or $40 \mathrm{mgl}^{-1}$ AS resulted in the higher average of shoots formation. Culture of Bribrí, Brunca, Guaymí, Huetar and Telire embryogenic axes on induction medium supplemented with different BAP and AS resulted in a differential response. Successful acclimatization of common bean in vitro plants were achieved in the greenhouse, and plants appeared morphologically normal. The regeneration system developed in this investigation for this important crop could be a useful tool for the genetic modification through mutagenesis or genetic transformation.

Common bean (Phaseolus vulgaris) is an economic important crop and one of the major grain legumes for human consumption in Latin America, Africa and Asia (Delgado-Sanchez et al. 2006; Varisai Mohamed et al. 2006). Despite its importance, production growth rates are limited by viral, fungal and bacterial pathogens, insects, lack of drought tolerances and nutritional deficiencies (Aragão et al. 1996). Therefore, there is considerable interest in the development of new bean cultivars with useful agronomical traits (Aragão et al. 1996).

Plant biotechnology, together with conventional breeding methods, could facilitate bean improvement since resistance or tolerance to biotic and abiotic stress could be increased and seed quality, plant architecture and reproduction modes could be altered (Veltcheva et al. 2005). Nevertheless, a reliable and efficient in vitro culture

*Corresponding author 


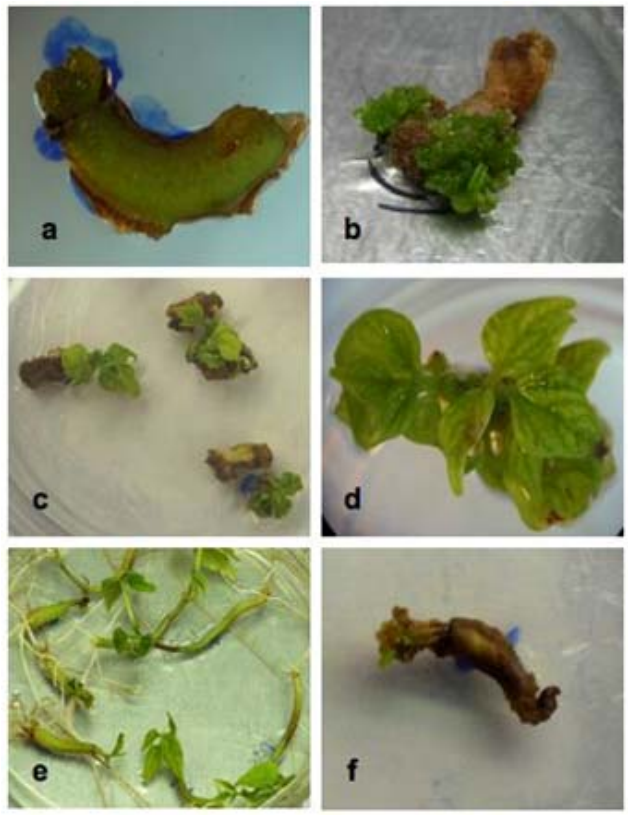

Figure 1. Apical bud cluster induction from embryogenic axesofcommon bean (Phaseolus vulgaris L.).

(a) embryogenic axes cultured on induction medium supplemented with BAP $\left(0,5\right.$ and $\left.10 \mathrm{mgl}^{-1}\right)$ and $A S(0,20$ and $40 \mathrm{mgl}^{-1}$ ).

(b) Bud clusters formed after 30 days in induction medium.

(c) Bud cluster propagation.

(d) Bean plant developed from bud clusters.

(e) Roots of germinated embryogenic axes.

(f) Phenolic oxidation observed on embryogenic axes.

system that results in efficient differentiation, shoot development and whole plant regeneration is an essential requirement for improvement of common bean through genetic transformation or mutagenesis (Svetleva et al. 2003; Varisai Mohamed et al. 2006). In addition to genetic improvement, in vitro culture is an important tool for the recovery, conservation of germplasm and embryo rescue (Delgado-Sanchez et al. 2006).

In vitro plant regeneration of Phaseolus has been reported by organogenesis (Malik and Saxena, 1991; Malik and Saxena, 1992; Ahmed et al. 2002; Veltcheva and Svetleva, 2005; Delgado-Sanchez et al. 2006; Varisai Mohamed et al. 2006) or through somatic embryogenesis (Zambre et al. 1998; Schryer et al. 2005). Although several protocols have been described in the literature for bean regeneration, development of an optimal in vitro culture system still remains a major challenge since this and other species from the Phaseolusgenus, are recalcitrant for in vitro regeneration (Veltcheva et al. 2005).

Therefore, the objective of the present study was to optimize an in vitro plant regeneration system for five commercial Costa Rican Phaseolus vulgaris cultivars by studying the influence of $\mathrm{N}^{6}$-benzylaminopurine and adenine sulphate, as a prerequisite for improvement of common bean through genetic transformation or mutagenesis.

\section{MATERIALS AND METHODS}

\section{Plant material and explant preparation}

Five Costa Rican common bean (Phaseolus vulgaris) cultivars -Bribrí, Brunca, Guaymí, Huetar and Telire- were obtained from Fabio Baudrit Moreno Experimental Station, University of Costa Rica. Seeds were washed with running tap water and soaked for $4 \mathrm{~min}$ in $70 \%$ ethanol, disinfected with $20 \%(\mathrm{v} / \mathrm{v})$ sodium hypochlorite with two drops of Tween 20 solution for 20 min and rinsed three times with sterile distilled water. Then, the seeds were immersed in 0.01\% Benomyl (Piscis, Costa Rica) solution for 4 min and rinsed three times with sterile distilled water. The seeds were soaked in sterile distilled water overnight at $26 \pm 2^{\circ} \mathrm{C}$ to soften the seed coat. The embryogenic axes were excised from the seeds and cotyledons and root meristems were removed.

\section{Induction and plant regeneration medium}

The embryogenic axes were cultured on Petri dishes containing $20 \mathrm{ml}$ of induction medium which consisted of MS mineral salts (Murashige and Skoog, 1962) supplemented with $100 \mathrm{mgl}^{-1}$ myo-inositol, $1 \mathrm{mgl}^{-1}$ thiamine, $30 \mathrm{gl}^{-1}$ sucrose and $8 \mathrm{gl}^{-1}$ agar. The induction medium was supplemented with a combination of BAP $(0$, 5 and $\left.10 \mathrm{mgl}^{-1}\right)$ and AS $\left(0,20\right.$ and $\left.40 \mathrm{mgl}^{-1}\right)$ to comprise 9 treatments (Delgado-Sanchez et al. 2006). Experimental treatments consisted of three replicates of three Petri dishes with 10 explants in each one. All medium $\mathrm{pH}$ was adjusted to 5.6 before autoclaving for $21 \mathrm{~min}$ at $121^{\circ} \mathrm{C}$ and $1.07 \mathrm{~kg}$ $\mathrm{cm}^{-2}$.

Table 1. Effect of genotype on the average number of shoots and leaves induced from embryogenic axesofcommon bean (Phaseolus vulgaris L.) regardless of the BAP and AS concentration. Data were recorded after 30 days of culture on induction medium supplemented with different BAP and AS concentrations.

\begin{tabular}{|l|l|l|}
\hline \multicolumn{1}{|c|}{ Genotype } & \multicolumn{1}{|c|}{ Shoots $^{1}$} & \multicolumn{1}{c|}{ Leaves $^{1}$} \\
\hline \hline Bribrí & $0.24 \pm 0.04^{2} \mathrm{~b}$ & $0.29 \pm 0.03 \mathrm{~b} \mathrm{c}$ \\
\hline Brunca & $0.57 \pm 0.06 \mathrm{a}$ & $0.42 \pm 0.05 \mathrm{~b}$ \\
\hline Guaymí & $0.06 \pm 0.01 \mathrm{c}$ & $0.34 \pm 0.04 \mathrm{~b} \mathrm{c}$ \\
\hline Huetar & $0.02 \pm 0.01 \mathrm{c}$ & $0.21 \pm 0.03 \mathrm{c}$ \\
\hline Telire & $0.38 \pm 0.04 \mathrm{~b}$ & $0.96 \pm 0.08 \mathrm{a}$ \\
\hline
\end{tabular}

${ }^{1}$ Values represent the average shoot and leaves $s$ formation per genotype in 9 Petri dishes with 10 explants and three replicates. ${ }^{2}$ Mean \pm SE

Same letters within columns denote statistically equal means with the Tukey Unequal N HSD test $(P<0.05)$. 


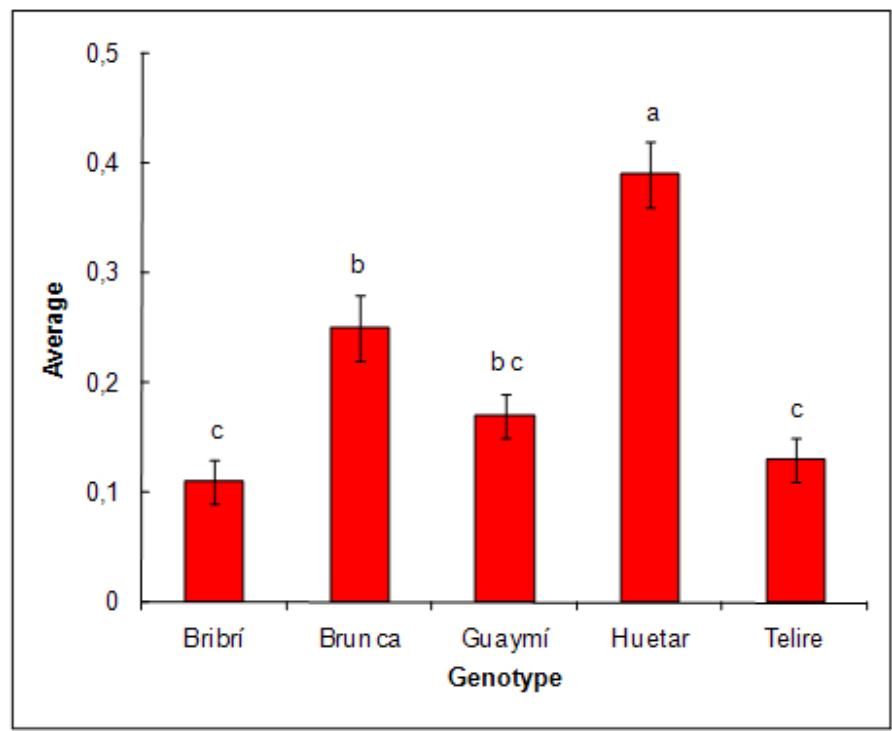

Figure 2. Effect of genotype on phenolic oxidation of embryogenic axesofcommon bean (Phaseolus vulgaris L. cvs. Bribrí, Brunca, Guaymí, Huetar and Telire) regardless of the BAP and AS concentration. Mean \pm SE. Values within columns followed by the same letter are not significantly different with the Tukey Unequal N HSD test $(P<0.05)$.

The shoots regenerated from bud clusters were excised from the original explant and transferred to baby food jars, closed with polyethylene food wrap (Glad, Costa Rica), containing $20 \mathrm{ml}$ of induction medium to promote elongation and root formation. The in vitro cultures were maintained at $26 \pm 2^{\circ} \mathrm{C}$ under a 16 hrs light photoperiod (30 $\mu \mathrm{mol} \mathrm{m} \mathrm{m}^{-2}$ ). The average number (mean $\pm \mathrm{SE}$ ) of shoots, leaves and roots per explant were estimated after 30 days of culture on each induction medium. The efficiency of the treatments [(Number of embryogenic axes with de novo shoots/total of embryogenic axes) x 100] were calculated.

\section{Acclimatization and field transfer}

Regenerated shoots (approximately $3 \mathrm{~cm}$ long) with well developed leaves and roots were transferred to pots containing Floragard Blumenerde potting soil (Floragard products, Germany), covered with plastic bags and maintained in the greenhouse under 12 hrs light photoperiod at $26 \pm 2^{\circ} \mathrm{C}$. After one week the plastic bags were removed. The plantlets were watered twice a week.

\section{Statistical analysis}

The statistical analysis was performed using one-way ANOVA and the significance of differences among treatment means were contrasted with Tukey's Honestly Significant Difference Test (HSD) at $\mathrm{P}<0.05$. The program STATISTICA (StatSoft, Tulsa, OK, USA)version 6.0 was used.

\section{RESULTS}

Multiple shoot formation began with the swelling of embryogenic axes (Figure 1a), and apical bud clusters formed after 30 days of culture (Figure $1 b$ ). The apical bud clusters were multiplied by culturing them in the induction medium (Figure 1c) until shoots were developed (Figure 1d).

The Table 1 show the effect of genotype on the average number of shoots, leaves and roots induced from embryogenic axes of common bean (Phaseolus vulgaris) regardless of the BAP and AS concentration. The average number of shoots and leaves differed significantly among the common bean cultivars evaluated. The higher multiple shoot formation was obtained using Brunca > Telire > Bribrí > Guaymí > Huetar. Moreover, the higher average of leaves was obtained using Telire $>$ Brunca $>$ Guaymí $>$ Bribrí > Huetar. On the other hand, no significant differences were observed in the number of roots formed from embryogenic axes cultured on induction medium supplemented with different BAP and AS concentrations (data not shown).

The effect of BAP and AS concentration on phenolic oxidation and average number of shoots, roots and leaves induced from embryogenic axesofcommon bean (Phaseolus vulgaris) regardless of the genotype is shown in the Table 2. Independently of the cultivar, significant differences were observed in the number of roots formed among the treatments evaluated. The higher number of roots per explant was obtained in the induction medium depleted of BAP and AS (Figure 1e). It was observed that as the BAP and AS concentrations increased, the number of roots per explant decreased (Table 2).

Moreover, regardless of the cultivar, the induction medium supplemented with $5 \mathrm{mgl}^{-1}$ BAP and 20 and $40 \mathrm{mgl}^{-1} \mathrm{AS}$ resulted in a higher average number of shoots (Table 2). On 
Table 2. Effect of BAP and AS concentration on phenolic oxidation and average number of shoots, roots and leaves induced from embryogenic axesofcommon bean (Phaseolus vulgaris L.) regardless of the genotype. Data were recorded after 30 days of culture on induction medium supplemented with different BAP and AS concentrations.

\begin{tabular}{|c|c|c|c|c|c|}
\hline \multicolumn{6}{|l|}{ Treatments } \\
\hline $\operatorname{BAP}\left(\mathrm{mgl}^{-1}\right)$ & AS $\left(\mathrm{mgl}^{-1}\right)$ & Shoots $^{1}$ & Leaves $^{1}$ & Roots $^{1}$ & Phenolic oxidation $^{1}$ \\
\hline 0 & 0 & $0.00 \pm 0.00^{2} \mathrm{~d}$ & $0.89 \pm 0.05 a$ & $3.53 \pm 0.18 a$ & $0.00 \pm 0.00 \mathrm{e}$ \\
\hline 0 & 20 & $0.00 \pm 0.00 \mathrm{~d}$ & $0.34 \pm 0.04 d$ & $1.85 \pm 0.16 b$ & $0.19 \pm 0.03 \mathrm{c} \mathrm{d}$ \\
\hline 0 & 40 & $0.37 \pm 0.04 b c$ & $0.81 \pm 0.07 a b$ & $0.65 \pm 0.05 c$ & $0.45 \pm 0.04 \mathrm{a}$ \\
\hline 5 & 0 & $0.09 \pm 0.04 d$ & $0.00 \pm 0.00 \mathrm{e}$ & $0.09 \pm 0.04 d$ & $0.00 \pm 0.00 \mathrm{e}$ \\
\hline 5 & 20 & $0.56 \pm 0.08 a b$ & $0.70 \pm 0.13 a b c$ & $0.01 \pm 0.01 d$ & $0.31 \pm 0.04 b c$ \\
\hline 5 & 40 & $0.66 \pm 0.09 a$ & $0.49 \pm 0.09 \mathrm{c} \mathrm{d}$ & $0.00 \pm 0.00 d$ & $0.05 \pm 0.02 \mathrm{de}$ \\
\hline 10 & 0 & $0.01 \pm 0.01 \mathrm{~d}$ & $0.00 \pm 0.00 \mathrm{e}$ & $0.00 \pm 0.00 d$ & $0.31 \pm 0.04 b c$ \\
\hline 10 & 20 & $0.20 \pm 0.06 \mathrm{c} \mathrm{d}$ & $0.25 \pm 0.06 \mathrm{~d} \mathrm{e}$ & $0.31 \pm 0.08 \mathrm{~cd}$ & $0.43 \pm 0.04 a b$ \\
\hline 10 & 40 & $0.40 \pm 0.05 b c$ & $0.51 \pm 0.08 b c d$ & $0.00 \pm 0.00 \mathrm{~d}$ & $0.15 \pm 0.02 d$ \\
\hline
\end{tabular}

${ }^{1}$ Values represent the average shoot, leaves and roots formation per treatment in 15 Petri dishes with 10 explants and three replicates.

${ }^{2}$ Mean \pm SE

Same letters within columns denote statistically equal means with the Tukey Unequal N HSD test $(P<0.05)$

the other hand, no shoots were observed in the induction medium supplemented with $0 \mathrm{mgl}^{-1} \mathrm{BAP}$ and 0 and $20 \mathrm{mgl}^{-}$ ${ }^{1} \mathrm{AS}$. It is important to mentioned that the leaves and roots formed with $0 \mathrm{mgl}^{-1} \mathrm{BAP}$ and 0 and $20 \mathrm{mgl}^{-1} \mathrm{AS}$ correspond to the germinated embryogenic axes and not from developed shoots (Table 2).

Table 3 shows the effect of BAP and AS on the number of shoots induced from embryogenic axes of Phaseolus vulgaris. Cultures of Bribrí, Brunca, Guaymí, Huetar and Telire embryogenic axes on induction medium supplemented with different BAP and AS resulted in a differential response. In all the cultivars evaluated, no organogenic bud clusters were induced using $0 \mathrm{mgl}^{-1} \mathrm{BAP}$ and 0 and $20 \mathrm{mgl}^{-1}$ AS after 30 days of culture. Addition of $40 \mathrm{mgl}^{-1}$ AS, combined with $0 \mathrm{mgl}^{-1}$ BAP, improved multiple shoot bud formation in Bribrí, Brunca, Huetar and Telire. In the Bribrí and Brunca cultivars, the higher average of shoots and the higher efficiency percentage were obtained using $5 \mathrm{mgl}^{-1}$ BAP combined with 20 or $40 \mathrm{mgl}^{-1}$ AS. For Guaymí and Huetar cultivars, no significant differences were observed among treatments; nevertheless, the best results were obtained using $0 \mathrm{mgl}^{-1}$ BAP with 40 $\mathrm{mgl}^{-1} \mathrm{AS}, 5 \mathrm{mgl}^{-1} \mathrm{BAP}$ with 20 and $40 \mathrm{mgl}^{-1} \mathrm{AS}$ or $10 \mathrm{mgl}^{-1}$ BAP with 20 and $40 \mathrm{mgl}^{-1}$ AS. In the Telire cultivar, the higher average number of shoots was obtained using $5 \mathrm{mgl}^{-}$ ${ }^{1}$ BAP combined with 20 AS or $10 \mathrm{mgl}^{-1}$ BAP with $40 \mathrm{mgl}^{-1}$ AS. Nevertheless, the higher efficiency percentage was obtained using $0 \mathrm{mgl}^{-1}$ BAP combined with 40 AS (Table $3)$.

Common bean in vitro plant regeneration is limited by phenolic oxidation (Figure 1f). The higher average of phenolic oxidation was observed using Huetar $(0.39 \pm$ $0.03)$, Brunca (0.25 \pm 0.03$)$, Guaymí $(0.17 \pm 0.02)$, Telire $(0.13 \pm 0.02)$ and Bribrí $(0.11 \pm 0.02)$, regardless of the concentration of BAP and AS (Figure 2). On the other hand, independently of the cultivar, no phenolic oxidation was observed in the explants cultured on the induction medium depleted of BAP and AS; whereas the higher average of phenolic oxidation was obtained using the induction medium supplemented with $0 \mathrm{mgl}^{-1} \mathrm{BAP}$ and 40 $\mathrm{mgl}^{-1} \mathrm{AS}, 5 \mathrm{mgl}^{-1} \mathrm{BAP}$ with $20 \mathrm{mgl}^{-1} \mathrm{AS}$ and $10 \mathrm{mgl}^{-1} \mathrm{BAP}$ and 0 and $20 \mathrm{mgl}^{-1}$ AS (Table 2).

The shoots regenerated from the apical bud clusters (Figure 1d) and developed into plants with leaves and roots (Figure 3a). The in vitro plants were successfully acclimated with $100 \%$ survival (Figure 3b). The entire procedure starting from apical bud cluster induction to establishing a plant under greenhouse conditions took approximately 3 months.

\section{DISCUSSION}

Regeneration protocols using different explants of Phaseolus spp. (Malik and Saxena, 1991, Malik and 

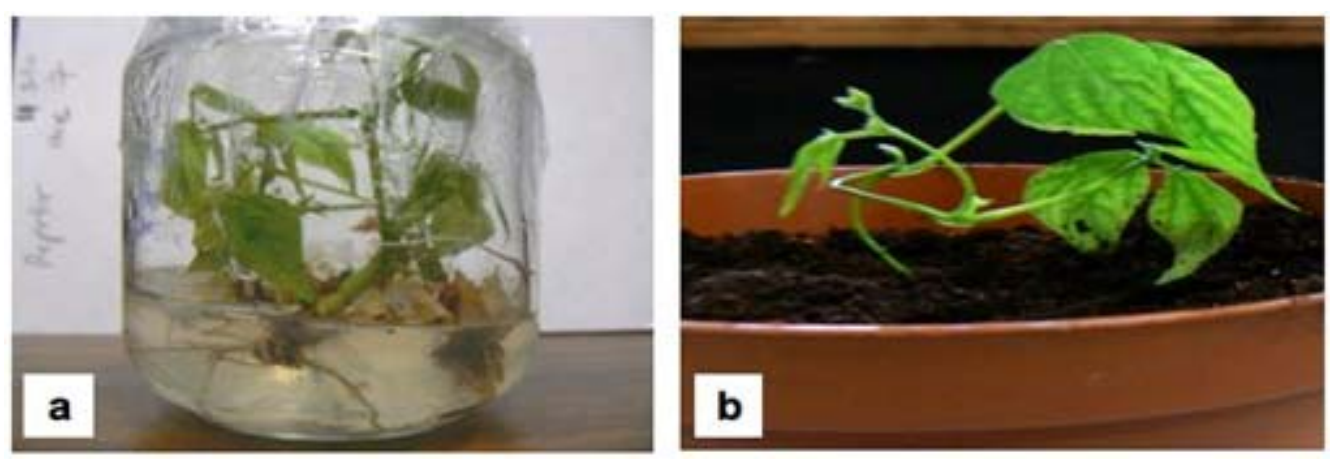

Figure. 3. (a) Bean plants regenerated from bud clusters after 60 days on induction medium. (b) Bean plants acclimated in the greenhouse.

Saxena, 1992; Ahmed et al. 2002; Veltcheva and Svetleva, 2005; Delgado-Sanchez et al. 2006; Varisai Mohamed et al. 2006; Arellano et al. 2009) have been described. This process in Phaseolus vulgaris has been histologically demonstrated by Malik and Saxena (1992) and Arellano et al. (2009). In the present study an efficient and reproducible method for regeneration of the commercially important Costa Rican common bean using BAP and AS was established.

Many factors induce development of new structures via organogenesis, but it has been demonstrated that regenerative capacity and response to growth conditions is species and genotype dependent as reported in Helianthus annuus (Deglene et al. 1997) and Solanum melongena. (Sharma and Rajam, 1995). Our results confirmed earlier observations that the genotype influences the regeneration process via organogenesis in the bean (Santalla et al. 1998; Veltcheva et al. 2005; Delgado-Sanchez et al. 2006; Varisai Mohamed et al. 2006). The genotype effects suggest that genetic factors are important in the response to in vitro tissue culture (Santalla et al. 1998). In this sense, due to the reduced genetic variability in modern bean cultivars, the screening of a large number of cultivars may be useful in the attempt to achieve plant regeneration (Svetleva et al. 2003; Veltcheva et al. 2005).

The composition of the shoot induction medium is important in the regeneration process through organogenesis since in this medium a higher number of buds and shoots are formed (Santalla et al. 1998). In this study, BAP and AS played an important role in the induction of organogenic structures in the Costa Rican bean cultivars evaluated. It is well known that cytokinins stimulate plant cell division and participate in the release of lateral bud dormancy, in the induction of adventitious bud formation, in the growth of lateral buds and in the cell cycle control (Gaspar et al. 1996; Gaspar et al 2003). Malik and Saxena (1991) reported that $5 \mu \mathrm{M}$ BAP had a favorable effect on shoot formation from cultured leaf explants of $P$. vulgaris compared to the explants cultured on MS medium depleted of BAP. Moreover, Varisai Mohamed et al. (2006) indicated that BAP and thidiazuron at $5 \mu \mathrm{M}$ was the best concentration for shoot formation in P. angularis (binomial name Vigna angularis) cvs. KS-6, KS-7 and KS-8 (azuki bean). In the absence of BAP, no shoot bud development was found in P. angularis. (Varisai Mohamed et al. 2006). Delgado-Sanchez et al. (2006) observed that 22.2 or $44 \mu \mathrm{M}$ BAP induced the formation of buds in two Mexican $P$. vulgaris cultivars. BAP has also been reported to be effective for shoot induction in P. vulgaris and P. coccineus (Malik and Saxena 1992; Santalla et al. 1998). The beneficial effects of BAP on adventitious shoot induction were also observed in other legumes such as Vigna angularis (Avenido and Hattori, 2000) and V. mungo (Saini and Jaiwal, 2002).

It has been demonstrated that adenine, adenosine and adelynic acid have cytokinin activity and they are added to the culture medium in order to improve growth or to reinforce the response normally attributed to cytokinin action. In this sense, adenine stimulates somatic embryogenesis and caulogenesis, enhances the growth of isolated meristem tips, induces the proliferation of axillary shoots in shoot cultures and promotes adventitious shoot formation indirectly from calli or directly from explants (van Staden et al. 2008).

The benefits of adenine are often only noticed when it is associated together with ammonium nitrate or with cytokinins such as BAP or kinetin (van Staden et al. 2008). Our results suggest that BAP, in combination with AS, improves the process of organogenesis. Several explanations for this are possible. One possibility is that adenine acts as a precursor for natural cytokinin synthesis or enhances natural cytokinin biosynthesis; the compounds produced could be more effective in causing the physiological response than the cytokinins added to the culture medium. Another possibility is that adenine acts as a synergist of cytokinins such as kinetin and zeatin. The natural and synthetic purine cytokinins are degraded to adenine and related nucleotides; therefore, the addition of adenine to the medium may retard the degradation of cytokinins by feed-back inhibition or by competing for the 
Table 3. The effect of BAP and AS on the number of shoots induced from embryogenic axes of Phaseolus vulgaris L. after 30 days of culture on induction medium supplemented with different BAP and AS concentrations.

\begin{tabular}{|c|c|c|c|c|c|c|}
\hline \multicolumn{2}{|c|}{ Treatments } & \multicolumn{5}{|c|}{ Shoots $^{1}{\text { (efficiency } \%)^{2}}^{2}$} \\
\hline$\underset{\left(\mathrm{mgl}^{-1}\right)}{\text { BAP }}$ & $\underset{\left(\mathrm{mgl}^{-1}\right)}{\mathrm{AS}}$ & Bribrí & Brunca & Guaymí & Huetar & Telire \\
\hline 0 & 0 & $0 \pm 0^{3} \mathrm{c}(0)$ & $0 \pm 0 c(0)$ & $0 \pm 0 \mathrm{a}(0)$ & $0 \pm 0 \mathrm{a}(0)$ & $0 \pm 0 c(0)$ \\
\hline 0 & 20 & $0 \pm 0 c(0)$ & $0 \pm 0 \mathrm{c}(0)$ & $0 \pm 0 \mathrm{a}(0)$ & $0 \pm 0 \mathrm{a}(0)$ & $0 \pm 0 \mathrm{c}(0)$ \\
\hline 0 & 40 & $0.03 \pm 0.03 \mathrm{c}(3)$ & $0.93 \pm 0.05$ b (93) & $0 \pm 0 \mathrm{a}(0)$ & $0.10 \pm 0.06 \mathrm{a}(10)$ & $0.80 \pm 0.07 \mathrm{ab}(80)$ \\
\hline 5 & 0 & $0 \pm 0 c(0)$ & $0.47 \pm 0.18$ b c (21) & $0 \pm 0 \mathrm{a}(0)$ & $0 \pm 0 \mathrm{a}(0)$ & $0 \pm 0 c(0)$ \\
\hline 5 & 20 & $1.20 \pm 0.22$ a (53) & $0.53 \pm 0.20 \mathrm{~b}(24)$ & $0.13 \pm 0.06 a(10)$ & $0 \pm 0 \mathrm{a}(0)$ & $0.93 \pm 0.15 a(67)$ \\
\hline 5 & 40 & $0.17 \pm 0.07 \mathrm{bc}(17)$ & $2.43 \pm 0.17$ a (96) & $0.17 \pm 0.07$ a (17) & $0.07 \pm 0.05$ a (7) & $0.45 \pm 0.11 \mathrm{abc}(60)$ \\
\hline 10 & 0 & $0.07 \pm 0.07$ bc (7) & $0 \pm 0 \mathrm{c}(0)$ & $0 \pm 0 \mathrm{a}(0)$ & $0 \pm 0 \mathrm{a}(0)$ & $0 \pm 0 \mathrm{c}(0)$ \\
\hline 10 & 20 & $0.50 \pm 0.17 b(20)$ & $0 \pm 0 c(0)$ & $0.13 \pm 0.06 \mathrm{a}(13)$ & $0 \pm 0 \mathrm{a}(0)$ & $0.37 \pm 0.25$ bc (10) \\
\hline 10 & 40 & $0.20 \pm 0.07 \mathrm{bc}(20)$ & $0.77 \pm 0.14 b(57)$ & $0.13 \pm 0.06 \mathrm{a}(13)$ & $0 \pm 0 \mathrm{a}(0)$ & $0.90 \pm 0.13 a(70)$ \\
\hline
\end{tabular}

${ }^{1}$ Values represent the average shoot formation in three Petri dishes with 10 explants and three replicates.

${ }^{2}$ [(Number of embryogenic axes with novo shoots/total of embryogenic axes) $\left.\times 100\right]$

${ }^{3}$ Mean \pm SE

Same letters within columns denote statistically equal means with the Tukey Unequal N HSD test $(P<0.05)$. Treatments that gave the best results of shoot formation are highlighted in bold.

enzyme systems involved in cytokinin metabolism (van Staden et al. 2008).

Adenine sulphate has been used for in vitro multiplication of Carica papaya (Saha et al. 2004; Schmildt et al. 2007), Musa sp. (Schmildt et al. 2007) and Uraria picta (Anand et al. 1998). Moreover, Nandagopal and Ranjitha Kumari (2006) used AS for shoot organogenesis induction in Cychorium intybus cv. Focus. Deshpande et al. (1998) indicated that a low concentration of cytokinins in combination with AS favors multiple shoot induction in Ficus religiosa. In black pepper (Piper nigrum), Philip et al. (1992) reported that AS increased the number of shoot buds per regenerating explant.

In contrast to our results, Delgado-Sanchez et al. (2006) reported that the application of AS at different concentrations did not produce a relevant increase in bud cluster formation in two Mexican common bean cultivars. Such divergent or contrasting results could be due to differences in cultivars, physiological state of explant and the season of explant collection.

On the other hand, higher concentration of cytokinin and AS generally delays root formation (van Staden et al. 2008) as seen in the present study (Table 2). In this sense, Delgado-Sanchez et al. (2006) reported that low BAP concentration ( 0 and $0.1 \mathrm{mgl}^{-1}$ ) induced only root formation and stem elongation.

The browning of the explant and surrounding culture media limit the establishment of in vitro cultures in several species, especially woody plant species. Browning is caused by the oxidation of phenolic compounds, released from the cut ends of the explants, by polyphenoloxidases, peroxidases or air (Bhat and Chandel, 1991; Laukkanen et al. 1999). In this sense, browning hampers the establishment of tissue culture in Aloe (Abrie and van Staden, 2001), Dioscorea alata (Bhat and Chandel, 1991), Musa spp. (Titov et al. 2006) and Pinus sylvestris (Laukkanen et al. 1999). Moreover, some plant growth regulators such as BAP, kinetin, TDZ, IAA alone or in combination with 2,4-D were reported to increase browning in Aloe species (Natali et al. 1990; Meyer and van Staden, 1991). Asahira and Nitsch (1969) reported that the addition of kinetin to the culture medium intensified the extend of browning in D. batatas and D. japonica. The application of BAP and kinetin enhanced biosynthesis of phenolic compounds in hairy roots of Panax ginseng (red ginseng). In contrast, the addition of auxins did not show an increase 
in the contents of total phenolic compounds in hairy roots of $P$. ginseng when no gibberellic acid or cytokinins were present (Jeong et al. 2007). Cytokinins are known to stimulate the synthesis of phenolic compounds (Asahira and Nitsch, 1969). Schnablova et al. (2006) reported that transgenic tobacco overproducing endogenous cytokinins accumulates more phenolic compounds during in vitro growth. (Reword: too many "overs"). Therefore, understanding the oxidation of phenols and how these can be minimized is critical for successful in vitro culture.

The in vitro protocol reported in this study could be used for clonal propagation of common bean and to obtain competent target tissue for genetic modification through in order to generate plants resistant to diseases and pests.

\section{ACKNOWLEDGMENTS}

The authors are grateful to María Isabel Morales and Jorge Mora Urpí (School of Biology, UCR) for language correction of the manuscript. Moreover, thanks are given to Ivannia Chinchilla for technical assistance.

\section{REFERENCES}

ABRIE, A.L. and VAN STADEN, J. Micropropagation of the endangered Aloe polyphylla. Plant Growth Regulation, January 2001, vol. 33, no. 1, p. 19-23.

AHMED, E.E.; BISZTRAY, G.Y.D. and VELICH, I. Plant regeneration from seedling explants of common bean (Phaseolus vulgaris L.). Acta Biologica Szegediensis, 2002, vol. 46, no. 3-4, p. 27-28.

ANAND, A.; SRINIVASA RAO, C.; LATHA, R.; JOSEKUTTY, P.C. and BALAKRISHNA, P. Micropropagation of Uraria picta, a medicinal plant, through axillary bud culture and callus regeneration. In vitro Cellular and Developmental Biology Plant, April 1998, vol. 34, no. 2, p. 136-140.

ARAGÃO, F.J.L.; BARROS, L.M.G.; BRASILEIRO, A.C.M.; RIBEIRO, S.G.; SMITH, F.D.; SANFORD, J.C.; FARIA, J.C. and RECH, E.L. Inheritance of foreign genes in transgenic bean (Phaseolus vulgaris L.) co-transformed via particle bombardment. Theoretical and Applied Genetics, July 1996, vol. 93, no. 1-2, p. 142-150.

ARELLANO, Jesús; FUENTES, Sara; CASTILLOESPAÑA, Patricia and HERNÁNDEZ, Georgina. Regeneration of different cultivars of common bean (Phaseolus vulgarisL.) via indirect organogenesis. Plant Cell Tissue and Organ Culture, January 2009, vol. 96, no. 1, p. 11-18.

ASAHIRA, T. and NITSCH, J.P. Effect of polarity and kinetin on the browning reaction of Dioscorea batatas and D. japonica. Planta, September 1969, vol. 84, no. 3, p. 292294.
AVENIDO, Renato A. and HATTORI, Kazumi. Benzyladenine-induced adventitious shoot regeneration from hypocotyls of adzukibean (Vigna angularis \{Willd\} Ohwi \& Ohashi). Plant Growth Regulation, July 2000, vol. 31, no. 3, p. 147-153.

BHAT, S.R. and CHANDEL, K.P.S. A novel technique to overcome browning in tissue culture. Plant Cell Reports, September 1991, vol. 10, no. 6-7, p. 358-361.

DEGLENE, Laurence; LESIGNES, Philippe; ALIBERT Gilbert and SARRAFI, Ahmad. Genetic control of organogenesis in cotyledons of sunflower (Helianthus annuus). Plant Cell Tissue and Organ Culture, February 1997, vol. 48, no. 2, p. 127-130.

DELGADO-SANCHEZ, P.; SAUCEDO-RUIZ, M.; GUZMÁN-MALDONADO, S.H.; VILLORDO-PINEDA, E.; GONZÁLEZ-CHAVIRA, M.; FRAIRE-VELÁZQUEZ, S.; ACOSTA-GALLEGOS, J.A. and MORA-AVILÉS, A. An organogenic plant regeneration system for common bean (Phaseolus vulgaris L.). Plant Science, April 2006, vol. 170, no. 4, p. 822-827.

DESHPANDE, S.R.; JOSEKUTTY, P.C. and PRATHAPASENAN, G. Plant regeneration from axillary buds of a mature tree of Ficus religiosa. Plant Cell Reports, April 1998, vol. 17, no. 6-7, p. 571-573.

GASPAR, Thomas; KEVERS, Claire; PENEL, Claude; GREPPIN, Hubert; REID, David M. and THORPE, Trevor A. Plant hormones and plant growth regulators in plant tissue culture. In vitro Cellular and Developmental Biology Plant, October 1996, vol. 32, no. 4, p. 272-289.

GASPAR, T.H.; KEVERS, C.; FAIVRE-RAMPANT, O.; CREVECOEUR, M.; PENEL, CL; GREPPIN, H. and DOMMES, J. Changing concepts in plant hormone action. In vitro Cellular and Developmental Biology Plant, March 2003, vol. 39, no. 2, p. 85-106.

JEONG, Gwi-Taek; WOO, Je-Chang and PARK, Don-Hee. Effect of plant growth regulators on growth and biosynthesis of phenolic compounds in genetically transformed hairy roots of Panax ginseng C. A. Meyer. Biotechnology and Bioprocess Engineering, 2007, vol. 12, no. 2, p. 86-91.

LAUKKANEN, Hanna; HÄGGMAN, Hely; KONTUNENSOPPELA, Sari and HOHTOLA, Anja. Tissue browning of in vitro cultures of Scots pine: Role of peroxidase and polyphenol oxidase. Physiologia Plantarum, July 1999, vol. 106, no. 3, p. 337-343.

MALIK, Kamal A. and SAXENA, Praveen K. Regeneration in Phaseolus vulgaris L. Promotive role of $\mathrm{N}^{6}$-benzylaminopurine in cultures from juvenile leaves. Planta, April 1991, vol. 184, no. 1, p. 148-150. 
MALIK, Kamal A. and SAXENA, Praveen K. Regeneration in Phaseolus vulgaris L.: High-frequency induction of direct shoot formation in intact seedlings by $\mathrm{N}^{6}$-benzylaminopurine and thidiazuron. Planta, February 1992, vol. 186, no. 3, p. 384-389.

MEYER H.J. and VAN STADEN, J. Rapid in vitro propagation of Aloe barbadensis Mill. Plant Cell Tissue and Organ Culture, September 1991, vol. 26, no. 3, p. 167171.

MURASHIGE, Toshio and SKOOG, Folke. A revised medium for rapid growth and bioassays with tobacco tissue cultures. Physiologia Plantarum, 1962, no. 15, p. 473-497.

NANDAGOPAL, S. and RANJITHA KUMARI, B.D. Adenine sulphate induced high frequency shoot organogenesis in callus and in vitro flowering of Cichorium intybus L. cv. Focus - a potent medicinal plant. Acta Agriculturae Slovenica, September 2006, vol. 87, no. 2, p. 415-425.

NATALI, Lucia; SANCHEZ, Isidro C. and CAVALLINI, Andrea. In vitro culture of Aloe bardadensis Mill.: Micropropagation from vegetative meristems. Plant Cell Tissue and Organ Culture, January 1990, vol. 20, no. 1, p. 71-74.

PHILIP, V.J.; JOSEPH, D.; TRIGGS, G.S. and DICKINSON, N.M: Micropropagation of black pepper (Piper nigrum Linn.) through shoot tip cultures. Plant Cell Reports, December 1992, vol. 12, no. 1, p. 41-44.

SAINI, Raman and JAIWAL, Pawan K. Age, position in mother seedling, orientation and polarity of the epicotyl segments of blackgram (Vigna mungo L. Hepper) determines its morphogenic response. Plant Science, July 2002, vol. 163, no. 1, p. 101-109.

SAHA, M.; PHATAK, A. and CHANDRA, N. In vitro culture studies in four dioecious varieties of Carica papaya L. using axillary buds from field-grown plants. Journal of Tissue Research, 2004, vol. 4, no. 2, p. 211-214.

SANTALLA, Marta; POWER, J. Brian and BAVEY, Michael R. Efficient in vitro shoot regeneration responses of Phaseolus vulgaris and P. coccineus. Euphytica, July 1998, vol. 102, no. 2, p. 195-202.

SCHMILDT, Omar; SCHMILDT, Edilson R. and AMARAL, Jose A.T. Sulfato de adenina na multiplicação in vitro de mamoeiro “Tainung 01". Scientia Agraria, 2007, vol. 8, no. 2, p. 141-147.

SCHNABLOVÁ, Renata; SYNKOVÁ, Helena; VIČÁNKOVÁ, Anna; BURKETOVÁ, Lenka; EDERC, Josef and CVIKROVÁ, Milena. Transgenic ipt tobacco overproducing cytokinins overaccumulates phenolic compounds during in vitro growth. Plant Physiology and Biochemistry, October 2006, vol. 44, no. 10, p. 526-534.
SCHRYER, P.A.; LU, Q.; VANDERBERG, A. and BETT, K.E. Rapid regeneration of Phaseolus angustissimus and $P$. vulgaris from very young zygotic embryos. Plant Cell Tissue and Organ Culture, October 2005, vol. 83, no. 1, p. 67-74.

SHARMA, Pankaj and RAJAM, Manchikatla V. Genotype, explant and position effects on organogenesis and somatic embryogenesis in eggplant (Solanum melongena L.). Journal of Experimental Botany, January 1995, vol. 46, no. 1, p. 135-141.

SVETLEVA, D.; VELCHEVA, M. and BHOWMIK, G. Biotechnology as a useful tool in common bean (Phaseolus vulgaris L) improvement. Euphytica, May 2003, vol. 131, no. 2, p. 189-200.

TITOV, S.; BHOWMIK, S.K.; MANDAL, A.; ALAM, M.S. and UDDIN, S.N. Control of phenolic compound secretion and effect of growth regulators for organ formation from Musa spp. cv. 'Kanthali' floral bud explants. American Journal of Biochemistry and Biotechnology, 2006, vol. 2, no. 3, p. 97-104.

VAN STADEN, J.; ZAZIMALOVA, E. and GEORGE, E.F. Plant growth regulators II: Cytokinins, their analogues and antagonist. In: GEORGE, E.F.; HALL, M. and DE KLECK, G.J. eds. Plant Propagation by Tissue Culture. vol 1. The Background. 2008. Springer, The Netherlands, p. 205-226.

VARISAI MOHAMED, Shamsudeen; SUNG, Jih-Min; JENG, Toong-Long and WANG, Chang-Sheng. Organogenesis of Phaseolus angularis L.: high efficiency of adventitious shoot regeneration from etiolated seedlings in the presence of N6-benzylaminopurine and thidiazuron. Plant Cell Tissue and Organ Culture, August 2006, vol. 86, no. 2, p. 187-199.

VELTCHEVA, Margarita and SVETLEVA, Diana. In vitro regeneration of Phaseolus vulgaris L. via organogenesis from petiole explants. Journal Central European Agriculture, April 2005, vol. 6, no. 1, p. 53-58.

VELTCHEVA, M.; SVETLEVA, D.; PETKOVA, Sp. and PERL, A. In vitro regeneration and genetic transformation of common bean (Phaseolus vulgaris L.) - Problems and progress. Scientia Horticulturae, December 2005, vol. 107, no. 1 , p. 2-10.

ZAMBRE, M.A.; DE CLERCQ, J.; VRANOVÁ, E.; VAN MONTAGU, M.; ANGENON, G. and DILLEN, W. Plant regeneration from embryo-derived callus in Phaseolus vulgaris L. (common bean) and P. acutifolius A. Gray (terapy bean). Plant Cell Reports, May 1998, vol 17, no. 8, p. 626-630. 